\title{
Algae: Critical Sources of Very Long-Chain Polyunsaturated Fatty Acids
}

\author{
John L. Harwood \\ School of Biosciences, Cardiff University, Cardiff CF10 3AX, UK; Harwood@Cardiff.ac.uk
}

Received: 10 October 2019; Accepted: 4 November 2019; Published: 6 November 2019

\begin{abstract}
Polyunsaturated fatty acids (PUFAs), which are divided into n-3 and n-6 classes, are essential for good health in humans and many animals. They are metabolised to lipid mediators, such as eicosanoids, resolvins and protectins. Increasing interest has been paid to the 20 or 22 carbon very long chain PUFAs, since these compounds can be used to form lipid mediators and, thus, avoid inefficient formation of dietary plant PUFAs. The ultimate sources of very long chain PUFAs are algae, which are consumed by fish and then by humans. In this review, I describe the biosynthesis of very long chain PUFAs by algae and how this synthesis can be manipulated for commercial purposes. Ultimately, the production of algal oils is critical for ecosystems worldwide, as well as for human dietary lipids.
\end{abstract}

Keywords: essential fatty acids; human requirement; eicosapentaenoic acid (EPA); docosahexaenoic acid (DHA); fish lipids; algal lipid synthesis

\section{Introduction}

Polyunsaturated fatty acids (PUFAs) are essential components in the diet of humans [1,2] and many other animals. There are two classes, which belong to the $n-3$ and the $n-6$ families. The basic precursors of these two families are alpha-linolenic and linoleic acids, respectively, and their dietary essentiality was first recognised 90 years ago [3,4]. However, because the PUFAs give rise to lipid signalling molecules or mediators, usually formed of 20 or 22 carbons, but are poorly converted to such precursor PUFAs, there is considerable interest in dietary 20 or 22C PUFA (very long chain PUFAs: VLCPUFA). Indeed, under certain conditions, such fatty acids may be 'conditionally essential' [5]. Thus, the dietary content of fatty acids, such as arachidonic (ARA), eicosapentaenoic (EPA) and docosahexaenoic (DHA), acids is important.

Dietary PUFA can be metabolised in animals to yield $20 \mathrm{C}$ or $22 \mathrm{C}$ products by a series of desaturation and elongation reactions (Figure 1). For DHA in mammals the synthesis from EPA involves the 'Sprecher pathway' [1,6], with a 24C intermediate and chain shortening by beta-oxidation. However, this biosynthetic route has recently been re-examined [7]. Once 20 or 22C PUFA have been produced they can be subject to oxidation by cyclooxygenase, lipoxygenase or epoxidase enzymes (Figure 2). This will give rise to a host of signalling molecules, the balance of which will depend on the substrates available, as well as the activity of the oxidases themselves. As a generalisation, n-6 PUFA give rise to inflammatory mediators, while the n-3 PUFA form neutral or anti-inflammatory signalling molecules [1]. Thus, the balance of (dietary) n-3 versus n-6 PUFA is important in determining overall physiological effect and it is thought that many modern 'Western diets' contain an excess of n-6 PUFA constituents. This can result in a chronic inflammatory situation which is of relevance to important diseases, such as arthritis, dementia or cardiovascular disease [8-10]. Western diets may contain a ratio of 15-20/1 (n-6/n-3 PUFA), but a ratio of about $4: 1$ has been recommended [11]. 


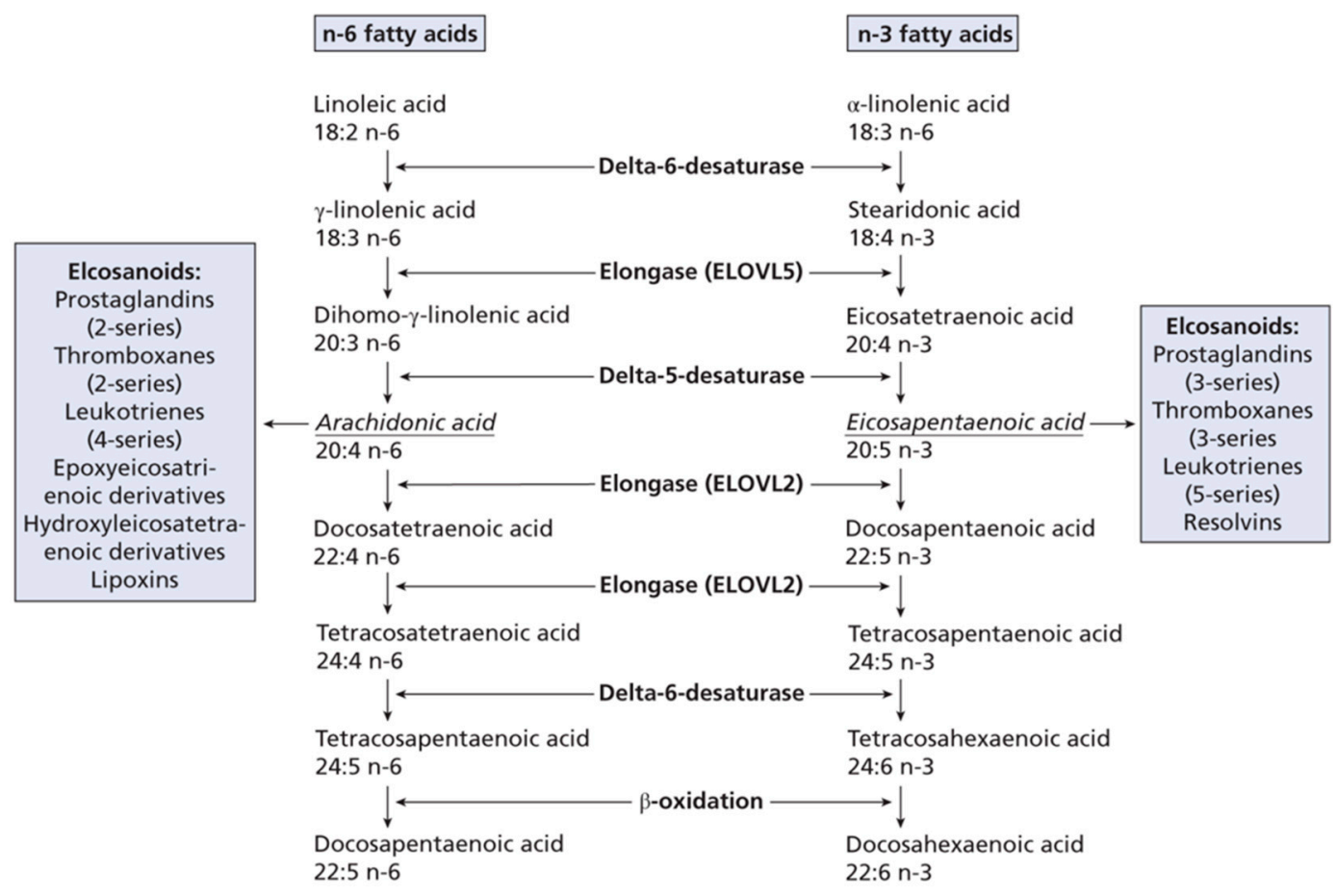

Figure 1. n-3 and n-6 fatty acid metabolism. Taken from [1], with permission. Lipids: Biochemistry, Biotechnology and Health, 6th ed. Gurr, M.I.; Harwood, J.L.; Frayn, K.N.; Murphy, D.J.; Michell, R.H. Wiley/Blackwell: Oxford, UK, 2016.

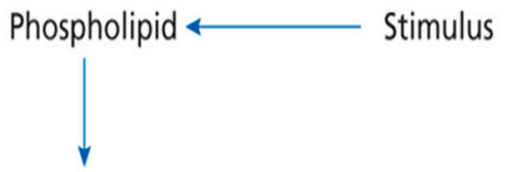

Precursor fatty acid (e.g. Arachidonate)

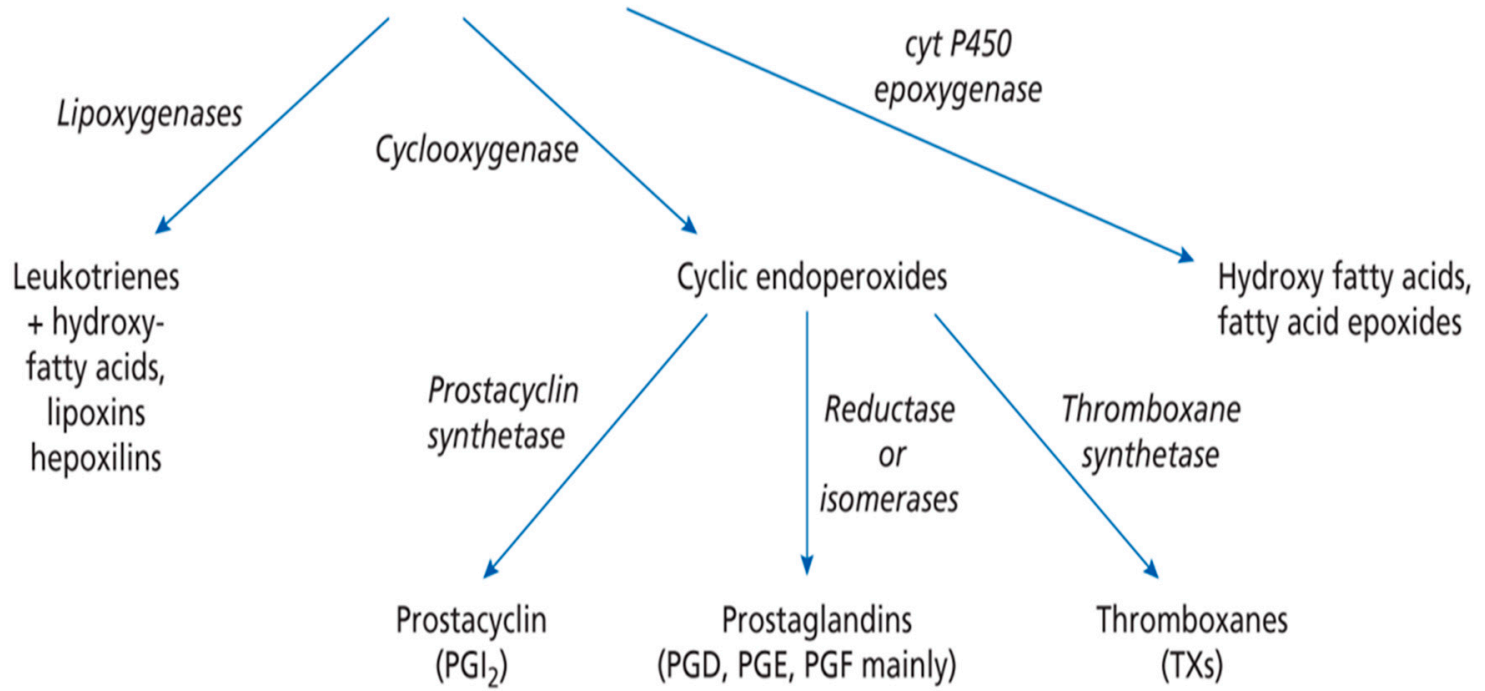

Figure 2. Overall pathway for the conversion of essential fatty acids into eicosanoids. Taken from [1], with permission. Lipids: Biochemistry, Biotechnology and Health, 6th ed. Gurr, M.I.; Harwood, J.L.; Frayn, K.N.; Murphy, D.J.; Michell, R.H. Wiley/Blackwell: Oxford, UK, 2016. 
Apart from their importance in giving rise to non-inflammatory eicosanoids, n-3 PUFA are also important in allowing the biosynthesis of some newly discovered lipid mediators [2,12-15]. Amongst these, resolvins, maresins and protectins are particularly important [1]. Resolvins act to resolve an acute inflammatory episode. Those derived from EPA are of the E series, while those from DHA are in the D series [1,16-18]. A single oxygenation found in human macrophages or platelets can give rise to a mediator termed maresin (macrophage mediator in resolving inflammation) [13]. Alternatively, protectins can be produced, of which the first to be discovered was neuroprotectin in brain tissue [19]. The production of resolvins, maresins and protectins from DHA finally gives a reason for the high amounts of DHA in neural tissue (see [11]).

Because of the inefficient production of EPA and DHA from alpha-linolenic acid (ALA) [20-22], the often overwhelming amount of linoleic acid (LA) in diets, and the increasing recognition of the importance of adequate n-3 PUFA for good health [11,20], the intake of dietary EPA and DHA has assumed considerable interest in recent years. Although fish are the main source of such acids for humans, EPA and DHA are produced de novo, mainly in algae. Thus, in recent years, there has been an accelerating interest in the biosynthesis of EPA and DHA in algae [23,24], and also in the use of genes from such algae to modify crop plants to produce 'fish oils' [25-30]. Moreover, many fish do not contain (or produce) significant amounts of EPA and DHA, and human dietary recommendations specify 'oily' fish as being necessary. When fish, such as salmon, are farmed, then fish meal or fish oil are needed to supplement the feed. Otherwise, the levels of EPA and DHA in the fish will be lowered dramatically [31]. Clearly, this is an unsustainable situation and emphasises the need to find alternative sources of VLCPUFA for fish farming — such as algae-derived additives.

As pointed out earlier, the 18C PUFAs, LA and ALA, are the basic essential fatty acids [3-5]. Although such acids can usually supply the basic human needs of VLCPUFA [5,31], there is a lot of evidence that dietary EPA and DHA have beneficial effects for good health. These benefits include reduced risk of widespread and important diseases, such as arthritis [32-34] and cardiovascular disease [35-38], and improved brain function. For the latter, three major epidemiological surveys have shown that significant amounts of n-3 PUFA in the diet can reduce the subsequent incidence of dementia [39-41]. Moreover, general brain function needs n-3 VLCPUFA [42] and supplementation can improve cognition in some patients [43,44]. In addition, a recent meta-analysis of various studies into nutrient supplements found that the strongest evidence for beneficial effects was for PUFAs (particularly EPA) as an adjunctive therapy for depression [45].

\section{Fish as a Source of Very Long Chain Polyunsaturated Fatty Acids}

While fish are a convenient (and usual) source of important lipids, such as the VLCPUFAs, many commercial fish (e.g., cod or tilapia) only contain small amounts of oil in their fillets. To satisfy human requirements, oily fish are needed. The fatty acid compositions of oils from important fish sources are shown in Table 1. It can be seen that n-3 VLCPUFA contents are in the range $14-31 \%$ of total fatty acids, with a wide-ranging EPA:DHA ratio. Because it seems clear that humans can interconvert these two fatty acids [7], it may not matter whether EPA or DHA is the dominant fish oil VLCPUFA. Nevertheless, because of the background of research and the known high concentrations of DHA in human (especially neurological) tissue, most attention has been paid to ensuring that DHA intakes are maintained. Although fish oils remain the most convenient source of n-3 VLCPUFA, there is increasing concern about the ability of this source to satisfy growing demand by humans, let alone their use in aquaculture. Indeed, most of the current supply of fish oils is used in aquaculture [46,47]. Moreover, there may be significant amounts of undesirable compounds (e.g., dioxins, mercury) in fish oils. Such hazardous contaminants can be removed [46], but this adds considerably to the manufacturing costs. These considerations emphasise the desirability of algae as a source of VLCPUFA. 
Table 1. Comparison of the fatty acid composition of some commercial fish oils.

\begin{tabular}{cccccccccc}
\hline & \multicolumn{7}{c}{ Fatty Acid (\% Total) } \\
\cline { 2 - 10 } & $\mathbf{1 4 : 0}$ & $\mathbf{1 6 : 0}$ & $\mathbf{1 6 : 1}$ & $\mathbf{1 8 : 1}$ & $\mathbf{2 0 : 1}$ & $\mathbf{2 0 : 5}$ & $\mathbf{2 2 : 1}$ & $\mathbf{2 2 : 5}$ & $\mathbf{2 2 : 6}$ \\
\hline Anchovy & 9 & 17 & 13 & 10 & 1 & 22 & 1 & 2 & 9 \\
Capelin & 7 & 10 & 10 & 14 & 17 & 8 & 15 & - & 6 \\
Cod Liver & 4 & 10 & 8 & 25 & 10 & 10 & 7 & 1 & 10 \\
Menhaden & 9 & 19 & 12 & 11 & 1 & 14 & - & 2 & 8 \\
Salmon * & 5 & 12 & 6 & 20 & 10 & 7 & 9 & 3 & 11 \\
Sardine & 8 & 18 & 10 & 13 & 4 & 16 & 3 & 2 & 9 \\
Tuna & 3 & 22 & 3 & 21 & 1 & 6 & 3 & 2 & 22
\end{tabular}

* Farmed salmon; 16:1, Palmitoleic acid; 18:1, oleic acid; 20:1, eicosenoic (gondoic) acid; 20:5, eicosapentaenoic acid; 22:1, docosenoic (erucic) acid; 22:5, docosapentaenoic acid (mainly 7, 10, 13, 16, 19 isomer); 22:6, docosahexaenoic acid (omega-3 isomer); Data taken from Gunstone et al. [46].

While much of the recent research on the benefits of dietary PUFAs has concentrated on humans, such fatty acids are important for other animals. Gladyshev and Sushchik have reviewed ecosystems, with regard to VLCPUFA [48]. There are many examples where various animals (e.g., zooplankton, Daphnia) benefit from an adequate supply of appropriate PUFA from algae (e.g., [49-52]). Moreover, fish themselves need an appropriate intake of PUFA in their diet $[47,53]$. Thus, there are more and more examples where algae (or new genetically-manipulated agricultural crops) are needed to reduce the current and future projected shortfalls in VLCPUFA. The anticipated shortage of VLCPUFA will only be made worse by climate change [54].

Given the increasing demand for VLCPUFA, as well as the problems with maintaining fish supplies, it is clear that this is a serious issue, that needs to be addressed urgently. Some calculations about the amounts of EPA and DHA which will be needed in the future [48] and possible shortfalls due to climate change [54] have been made.

\section{Algal Production of Polyunsaturated Fatty Acids}

The major lipid classes in algae are membrane components (betaine ether lipids, glycosylglycerides, phosphoglycerides) and storage lipids (mainly triacylglycerols) [23,24]. Numerous other compounds are found in small amounts [23]. Depending on the alga, the proportions of the polar membrane lipids may vary considerably [24] but they all tend to have a high concentration of PUFA. Evaluation of the overall fatty acid composition of algae, in addition to their location in different acyl lipids, have been well summarised $[23,24,55,56]$. Moreover, some algae have been successfully used for 'single cell oils' [57].

Recently, our knowledge of algal fatty acid composition has been enhanced by the establishment of the SAG culture collection (Culture Collection at the University of Gottingen, Germany). The fatty acid composition of individual algae and their lines (as grown to stationary phase) have been surveyed [58]. Some examples, which emphasise not only the wide fatty acid composition of different algae, but also their variability even within the same class, are shown in Table 2 . It should be noted that growth conditions, seasonal variations and developmental stages will all impact the overall fatty acid composition of algae, in addition to the patterns for individual lipid classes $[23,55,56,59]$. 
Table 2. Major fatty acids in a variety of freshwater and marine algae (data taken from $[55,58]$ ).

\begin{tabular}{|c|c|c|c|c|c|c|c|c|}
\hline & $16: 0$ & $16: 1$ & 18:1 & n6-18:2 & n3-18:3 & n6-20:4 & n3-20:5 & n3-22:6 \\
\hline Chlamydomonas reinhardtii_-1 & 20 & 4 & 15 & - & 22 & - & - & - \\
\hline Dunaliella salina_- ${ }^{1}$ & 27 & - & 11 & 4 & 36 & - & - & - \\
\hline Scenedesmus obliquus_-1 & 31 & - & 7 & 8 & 11 & - & - & - \\
\hline Chlorella vulgaris_-2 & 11 & 16 & 3 & 25 & 30 & - & - & - \\
\hline Lauderia borealis_- 3 & 12 & 21 & 2 & 1 & - & 1 & 3 & - \\
\hline Phaeodactylum tricornutum-3 & 19 & 25 & 8 & 6 & 1 & 1 & 18 & 1 \\
\hline Nannochloropsis gaditana—4 & 15 & 30 & 5 & - & 9 & 4 & 35 & - \\
\hline Emilia huxleyi_5 & 19 & 10 & 20 & - & - & - & - & 9 \\
\hline Pavlova lutheri_5 & 20 & 26 & 2 & 1 & 1 & - & 18 & 10 \\
\hline Ectocarpus siliculosus_-6 & 15 & - & - & 6 & 30 & 10 & 13 & - \\
\hline Fucus vesiculosus_ 6 & 21 & 2 & 26 & 10 & 7 & 15 & 8 & - \\
\hline Chondrus crispus_- ${ }^{7}$ & 34 & 6 & 9 & 1 & 1 & 18 & 22 & - \\
\hline Porphyridium purpureum—7 & 25 & - & - & 23 & - & 39 & 13 & - \\
\hline
\end{tabular}

As discussed in previous reviews $[24,25,55,56]$, certain classes of algae contain notable amounts of VLCPUFA. For example, brown algae are often enriched in arachidonate (ARA) [55], while red algae can have significant EPA. Sometimes, the EPA occurs with ARA (as in C. crispus) $[55,60]$ or without (as in Palmaria palmata, where EPA can represent half of the total fatty acids) [60,61].

De novo production of fatty acids in eukaryotic algae begins with the activity of acetyl-CoA carboxylase and fatty acid synthase within the chloroplasts. Information about individual enzymes and their regulation has been based on higher plant systems [62], which was then supplemented by work with the model green alga Chlamydomonas reinhardtii $[63,64]$. Since then, further detailed examination of several algae, including the eustigmatophyte Nannochloropsis spp., the diatom Phaeodactylum tricornutum and the red alga, Cyanidioschyzon merolae [65-71], suggested that fatty acid synthesis is similar to that in C. reinhardtii and, hence, in higher plants [62,72-74]. Details of the enzymes involved in de novo fatty acid synthesis are provided in a recent review [24].

As in higher plants, algal fatty acid synthesis in chloroplasts results in 16 and 18-carbon products. Whole further desaturations can take place in plastids. Production of VLCPUFA usually requires a mixture of elongation and desaturation on the endoplasmic reticulum (ER). Thus, fatty acids have to move from the chloroplast through the cytosol to the ER. This process has been compared between algae and higher plants [72,75].

Production of VLCPUFA has been examined in detail in Phaeodactylum tricornutum [71], where high amounts of EPA are made (Table 2), as well as in several other species (see [24]). The conventional delta6-pathway begins with linoleic (LA) or alpha-linolenic (ALA) acids. This involves delta6-desaturase, delta6-elongase and delta5-desaturase activities to produce ARA or EPA, respectively, as end-products [24,69]. Further chain lengthening to 22C products (n-6DPA or DHA) uses a delta5-elongase and a delta4-desaturase. Notably, this differs from the 'Sprecher pathway' in mammals (see [6,7]). Although the conventional delta6-pathway seems the most common method of producing VLCPUFA in algae, an alternative route (delta8-pathway) has been found in certain species [24]. Moreover, some algae have omega3- (or delta15-) desaturases, that can convert n-6 PUFA to n-3 PUFA $[69,76,77]$.

In some Thraustochytriaceae a polyketide synthase (PKS) can form VLCPUFA. For example, PKS is used by Schizochytrium [78], whereas, in Thraustochytrium, the desaturase/elongation pathway is utilised (see [24]). Several reviews cover the production of VLCPUFA in algae $[66,71,79]$.

As mentioned above, although LA and ALA are the main fatty acids and are considered the core 'essential fatty acids', they are poorly converted to ARA, EPA and DHA, which are the actual metabolic precursors for lipid mediators. Thus, Cunnane has argued for 'conditional requirements' of 
VLCPUFA in the diet [5]. Moreover, the perceived need for more n-3 PUFA in human diets has also led to increased consumption of oily fish (or their oils) as a convenient source of EPA and/or DHA. However, with problems due to over-fishing, as well as the increased demand for more dietary n-3 PUFA [80], this is not sustainable for the future [81-83].

The above conundrum has led to a serious examination of algae to supplement the demand for n-3 PUFA, especially EPA and DHA, for human nutrition. As discussed in [48], it is generally thought that 'many animals' and 'most invertebrates' need to have EPA and DHA in their diet, because of their limited ability to synthesise them from ALA [84]. However, quantitative evidence is currently somewhat lacking [48]. Nevertheless, mammals (like humans) have definite requirements and this has led to extensive use of rodent models for cardiovascular or dementia research [85]. However, availability of n-3 VLCPUFA, especially DHA, is projected to decline globally, due to climate change [54]. The latter causes water temperatures to rise with the consequence that algae contains less VLCPUFA (e.g., [86]).

\section{Factors Regulating PUFA Formation in Algae}

Lipid metabolism in algae is strongly influenced by many environmental factors, which include nutrition (notably N, P and S, and especially their limitation), general conditions (light, $\mathrm{pH}$, temperature) and, of course, toxic materials (e.g., heavy metals) [23,56]. Of interest in the general context of algal utilisation for oils, is that such stresses often cause the accumulation of triacylglycerol (TAG) [24,87].

Clearly, nitrogen is a basic constituent, needed for growth, and minimal requirements have been measured, for example, in Chlorella vulgaris [88]. On the other hand, low nitrogen stress will cause accumulation of TAG in green microalgae or diatoms to $20-50 \%$ dry weight [24,89]. Naturally, this phenomenon has been mainly studied in algae that offer commercial possibilities, either for biomass/biofuel production or for the biosynthesis of n-3 VLCPUFA. Thus, species such as P.tricornutum or Nannochloropsis have been studied in detail. The accumulation of TAG is caused by a combination of increased de novo synthesis, as well as transfer of fatty acids from membrane lipids [24]. For N. gaditana, the transfer of fatty acids comes from a decline in galactolipids and re-organisation of the photosynthetic apparatus [90]. In agreement, in P. tricornutum, the important chloroplast thylakoid constituents monogalactosyldiacylglycerol (MGDG) and phosphatidylglycerol (PtdGro), were reduced considerably, whereas other membrane lipids were largely unaffected [91]. Other details of the effects of N-limitation are covered in [24]. The overall processes can be regulated by a nitrogen response regulator [92], by nitrate reductase expression [93], and by a transcription factor (termed ROC40) [94].

One of the other major nutrients, phosphorus, can also affect lipid metabolism. Clearly, it is required for phospholipid biosynthesis, and P-starvation reduces the amounts of all phosphoglycerides [95]. P-limitation seems to cause a major change in the balance of different lipid classes, and not just phospholipids. For example, the important role of PtdGro in thylakoid functions can be partly replaced by substitution with another anionic lipid, the plant sulpholipid (sulphoquinovosyldiacylglycerol, SQDG). These alterations are described in detail in two reviews [23,24]. In addition, phosphorus deficiency can also cause an accumulation of TAG and, hence, increase algal oil content $[65,91,96]$.

For many diatoms, silicon is a macronutrient, and this includes many oleaginous species [97]. In addition, silicon depletion will increase TAG accumulation in those diatom species that require it $[98,99]$. P. tricornutum, on the other hand, seems to have little requirement for silicon, although this element can benefit growth [24,100].

As mentioned above, there is increasing concern that increases in environmental temperatures (either chronically in the oceans or transiently in streams and ponds) will decrease algal contents of PUFAs and, in particular, VLCPUFAs [54]. Growth in temperature will influence both fatty acid proportions, as well as lipid class composition $[23,24,56]$. Although many algal cultures exhibit maximal growth in the $20-30{ }^{\circ} \mathrm{C}$ range, different species are found in nature to grow at a wide variety of temperatures, ranging from the polar regions to hot springs. Temperature stress can be used to enhance production of valuable metabolites or to alter lipid content of different species $[23,24]$. 
General responses to altered ambient temperature in terms of growth, lipid proportions and fatty acid percentages have been described $[23,24,56]$. In terms of commercial production of algae, changes in lipid quantity and quality are most important. As a generalisation, increased lipid production is often found with temperature stress above the optimal growth values. However, high temperatures usually result in significantly less PUFA proportions. So commercial production may need to consider the main use of the end product. For example, reduced PUFA contents may be desirable if the algae are to be used for biofuel purposes. In contrast, for nutritional applications, lower growth temperatures, which encourage increased PUFA proportions, will be needed. For global PUFA availability [54], temperature stress is very important and specific studies using green microalgae have demonstrated this unequivocally $[84,101,102]$. Of course, reduced PUFA contents in algae will feed through to higher trophic levels, with implications for invertebrates, for fish and, consequently, human health.

\section{Algae as Commercial Sources of VLCPUFAs}

As discussed above, essential fatty acids (EFA) are needed by mammals and, indeed, many (most?) animals. The VLCPUFAs which are 'conditionally' important [5] are produced by algae. Moreover, such acids are needed for good health and a significant dietary deficit may be implicated in many important diseases. Although EFAs (LA, ALA) are provided by higher plant sources, currently very few populations receive adequate n-3 PUFA. Since the enzymes producing lipid mediators are usually active with both n-3 and n-6 precursors (mainly LA and ALA), their ratio in foods is critical. With a dietary ratio of 3:4 for n-6/n-3 PUFA being currently advised $[2,103,104]$, increasing supplies of n-3 PUFA, especially EPA and DHA, are needed. Thus, the commercial requirements for such acids, especially as fish feed in aquaculture, has increased.

The primary producers of PUFAs are photosynthetic organisms, with algae as the main source of EPA and DHA [105]. With the obvious limitation in future fish supplies, commercial usage of algae has increased. Oils from Crypthecodinium cohnii ('DHASCO') [106] and from Schizochytrium spp. [57] are commercially successful, especially for infant nutrition. Algal oils have some advantages over fish oils. They are usually enriched in a single n-3 VLCPUFA and will be devoid of potentially toxic compounds that may be present in fish [57]. Furthermore, because fish are often poor at converting ALA (or LA) into VLCPUFA [107], fish oils are used extensively in aquacultures. Currently, around $75 \%$ of marine fish oils are used in aquaculture [108] and this has led to the increasing use of algae as sources of VLCPUFA in fish feeds $[109,110]$. Several algal species are commercially viable as sources of n-3 VLCPUFA. Nannochloropsis spp. and P. tricornutum can accumulate EPA to about $40 \%$ of their total fatty acids $[111,112]$. Sources of DHA, with $30-40 \%$ of total fatty acids, are Thraustochytrium or Schizochytrium spp. [113].

The production of EPA by microorganisms and factors affecting its production have been summarised [114]. As noted above, Nannochloropsis spp. (e.g., N. gaditana, N. oculata) and P. tricornutum have been well researched [115,116], but other species, such as Trachydiscus minutus [117], are being considered. As with most algae, $\mathrm{N}$ and $\mathrm{P}$ supplies can influence lipid accumulation in the latter alga [118]. There has been some work on the genetic modification of P. tricornutum [119] and other algae in order to increase productivity [120]. Indeed, knowledge of the basic biochemistry of Chlamydomonas can be applied to commercial algae such as Nannochloropsis [24]. Exploitation of algae for EPA production has included not only Nannochloropsis [121], but also other species [121,122], such as Odontella aurita [123].

For DHA, the first commercial single cell oil was from a dinoflagellate, C. cohnii. There are more than 2000 dinoflagellates that have been identified, of which about half can grow without light. DHA accumulation in C.cohnii has been thoroughly discussed [122] and the use of different substrates described (see [24]). Schizochytrium, together with C. cohnii, has been used for over a decade in the infant milk formula market [122]. Commercial production of DHA by Schizochytrium is described in [124]. These thraustochytrids synthesise DHA using a PKS system [76], rather than the usual desaturation/elongation pathway. The possible manipulation of algae, including Schizochytrium, to 
produce more n-3 VLCPUFA has been reported [125]. In addition, the use of Schizochytrium oils for food or drink additives has been evaluated [124].

Farmed seaweeds are also important and, in 2016, approached 28 million tonnes (wet weight) [126]. Indeed, farmed seaweeds represent $96 \%$ of the total global seaweed supply [126]. This farming is mainly in Asia, where six countries produce $98 \%$ of the total supply. Indeed, in the Philippines some $70 \%$ of the total aquaculture production is aquatic plants, including seaweeds, making the country the second largest producer [127].

Overall reviews of VLCPUFA production by algae have been made $[66,71,79,128]$. Not only are such acids increasingly used for human nutrition, including in the modification of eggs, meat and milk, but they are also used in pet foods [129] and, especially, in aquaculture [122,130-132].

\section{Conclusions}

The importance of VLCPUFA in global ecosystems has been emphasised recently, partly due to climate change, but often driven by the important role of n-3 VLCPUFA for human health. Although fish oils are the main sources of dietary EPA and DHA for humans, these acids are produced de novo by algae. Thus, the biosynthesis of n-3 VLCPUFAs is being increasingly studied in algae, especially commercial species. In turn, algal enzymes used for VLCPUFA formation have been used in transgenic crops. By these means, algae are critical for the future production of EPA and DHA and, thus, for the sustainability of global ecosystems.

Funding: The author's work on algae has been funded by grants from the Natural Environment Research Council.

Conflicts of Interest: The author has no conflict of interest.

\section{References}

1. Gurr, M.I.; Harwood, J.L.; Frayn, K.N.; Murphy, D.J.; Michell, R.H. Lipids: Biochemistry, Biotechnology and Health, 6th ed.; Wiley/Blackwell: Oxford, UK, 2016.

2. Lands, B. Historical perspectives on the impact of n-3 and n-6 nutrients in health. Prog. Lipid Res. 2014, 55, 17-29. [CrossRef] [PubMed]

3. Burr, G.O.; Burr, M.M. A new deficiency disease produced by the rigid exclusion of fat from the diet. J. Biol. Chem. 1929, 82, 345-367. [CrossRef] [PubMed]

4. Burr, G.O.; Burr, M.M. The nature and role of the fatty acids essential in nutrition. J. Biol. Chem. 1930, 86, 587-621. [CrossRef]

5. Cunnane, S.C. Problems with essential fatty acids: Time for a new paradigm. Prog. Lipid Res. 2003, 42, 544-568. [CrossRef]

6. Voss, A.; Reinhart, M.; Sankarappa, S.; Sprecher, H. The metabolism of 7, 10, 13, 16, 19-docosapentaenoic acid to $4,7,10,13,16,19$-docosahexaenoic acid in rat liver is independent of a 4-desaturase. J. Biol. Chem. 1991, $266,19995-20000$.

7. Metherel, A.H.; Bazinet, R.P. Updates to the n-3 polyunsaturated fatty acid biosynthesis pathway: DHA synthesis rates, tetracosahexaenoic acid and (minimal) retroconversion. Prog. Lipid Res. 2019, 76, 101008. [CrossRef]

8. Harwood, J.L.; Caterson, B. Dietary omega-3 polyunsaturated fatty acids and inflammation. Lipid Technol. 2006, 18, 7-10.

9. Calder, P.C. Polyunsaturated fatty acids, inflammation and immunity. Lipids 2001, 36, 1007-1024. [CrossRef]

10. Calder, P.C. Polyunsaturated fatty acids and inflammation. Prostaglandins Leukot. Essent. Fat. Acids 2006, 75, 197-202. [CrossRef]

11. Hall, J.H.; Harwood, J.L. Brain lipids in health and disease. In Food Lipids: Chemistry, Nutrition and Biotechnology, 4th ed.; Akoh, C.C., Ed.; CRC Press: Boca Raton, FL, USA, 2017; pp. 747-764.

12. Schmitz, G.; Ecker, J. The opposing effects of n-3 and n-6 fatty acids. Prog. Lipid Res. 2008, 47, 147-155. [CrossRef]

13. Stables, M.J.; Gilroy, D.W. Old and new generation lipid mediators in acute inflammation and resolution. Prog. Lipid Res. 2011, 50, 35-51. [CrossRef] [PubMed] 
14. Astarita, G.; Kendall, A.; Dennis, E.A.; Nicolaou, A. Targeted lipidomic strategies for oxygenated metabolites of polyunsaturated fatty acids. Biochim. Biophys. Acta 2015, 1851, 456-468. [CrossRef] [PubMed]

15. Kim, H.Y.; Spector, A.A. N-Docosahexaenoylethanolamine: A neurotrophic and neuroprotective metabolite of docosahexaenoic acid. Mol. Asp. Med. 2018, 64, 34-44. [CrossRef] [PubMed]

16. Serhan, C.N.; DeWitt, D.1.; Garavito, R.M. Resolving inflammation: Dual anti-inflammatory and pro-resolution lipid mediators. Rev. Immunol. 2008, 8, 349-361. [CrossRef] [PubMed]

17. Ji, R.-R.; Xu, Z.-Z.; Strichartz, G.; Serhan, C.N. Emerging roles of resolvins in the resolution of inflammation and pain. Trends Neurosci. 2011, 34, 599-609. [CrossRef]

18. Serhan, C.N.; Chiang, N.; Dalli, J. New pro-resolving n-3 mediators bridge resolution of infectious inflammation to tissue regeneration. Mol. Asp. Med. 2018, 64, 1-17. [CrossRef]

19. Bazan, N.G. Omega-3 fatty acids, pro-inflammatory signalling and neuroprotection. Curr. Opin. Clin. Nutr. Metab. Care 2007, 10, 136-141. [CrossRef]

20. Zhang, T.-T.; Xu, J.; Wang, Y.-M.; Xue, C.-H. Health benefits of dietary marine DHA/EPA-enriched glycerophospholipids. Prog. Lipid Res. 2019, 75, 100997. [CrossRef]

21. Burdge, G.C.; Calder, P.C. Conversion of alpha-linolenic acid to longer-chain polyunsaturated fatty acids in human adults. Reprod. Nutr. Dev. 2005, 45, 581-597. [CrossRef]

22. Domenichiello, A.F.; Kitson, A.P.; Bazinet, R.P. Is docosahexaenoic acid synthesis from alpha-linolenic acid sufficient to supply the adult brain. Prog. Lipid Res. 2015, 59, 54-66. [CrossRef]

23. Guschina, I.A.; Harwood, J.L. Lipids and lipid metabolism in eukaryotic algae. Prog. Lipid Res. 2006, 45, 160-186. [CrossRef] [PubMed]

24. Li-Beisson, Y.; Thelen, J.J.; Fedosejevs, E.; Harwood, J.L. The lipid biochemistry of eukaryotic algae. Prog. Lipid Res. 2019, 74, 31-68. [CrossRef] [PubMed]

25. Wu, G.; Truksa, M.; Dada, N.; Vrinten, P.; Bauer, J.; Zank, T.; Cirpus, P.; Heinz, E.; Qiu, X. Stepwise engineering to produce high yields of very long-chain polyunsaturated fatty acids in plants. Nat. Biotechnol. 2005, 23, 1013-1017. [CrossRef] [PubMed]

26. Petrie, J.R.; Shrestha, P.; Zhou, X.-R.; Mansour, M.P.; Liu, Q.; Belide, S.; Nichols, P.D.; Singh, S.P. Metabolic engineering plant seeds with fish oil-like levels of DHA. PLOS ONE 2012, 7, e49165. [CrossRef]

27. Ruiz-Lopez, N.; Haslam, R.P.; Napier, J.A.; Sayanova, O. Successful high-level accumulation of fish oil omega-3 long-chain polyunsaturated fatty acids in a transgenic oilseed crop. Plant J. 2014, 77, 198-208. [CrossRef]

28. Napier, J.N.; Usher, S.; Haslam, R.P.; Ruiz-Lopez, N.; Sayanova, O. Transgenic plants as a sustainable, terrestrial source of fish oils. Eur. J. Lipid Sci. Technol. 2015, 117, 1317-1324. [CrossRef]

29. Usher, S.; Haslam, R.P.; Ruiz-Lopez, N.; Sayanova, O.; Napier, J.A. Field trial evaluation of the accumulation of omega-3 long chain polyunsaturated fatty acids in transgenic Camelina sativa: Making fish oil substitutes in plants. Metab. Eng. Commun. 2015, 2, 93-98. [CrossRef]

30. Walsh, T.A.; Bevan, S.A.; Gachotte, D.J.; Larsen, C.M.; Moskal, W.A.; Merlo, P.O.; Sidorenko, L.V.; Hampton, R.E.; Stoltz, V.; Pareddy, D.; et al. Canola engineered with a microalgal polyketide synthase-like system produces oil enriched in docosahexaenoic acid. Nat. Biotechnol. 2016, 34, 881-887. [CrossRef]

31. Sprague, M.; Dick, J.R.; Tocher, D.R. Impact of sustainable feeds on omega-3 long-chain fatty acid levels in farmed Atlantic salmon, 2006-2015. Sci. Rep. 2016, 6, 21892. [CrossRef]

32. Calder, P.C. Very long-chain n-3 fatty acids and human health: Fact, fiction and the future. Proc. Nutr. Soc. 2018, 77, 52-72. [CrossRef]

33. Rosell, M.; Wesley, A.M.; Rydin, L.; Klareskog, L.; Alfredsson, E.S. Dietary fish and fish oil and the risk of rheumatoid arthritis. Epidemiology 2009, 20, 896-901. [CrossRef] [PubMed]

34. Curtis, C.L.; Rees, S.G.; Cramp, J.; Flannery, C.R.; Hughes, C.E.; Little, C.B.; Williams, R.; Wilson, C.; Dent, C.M.; Harwood, J.L.; et al. Effects of n-3 fatty acids on cartilage metabolism. Proc. Nutr. Soc. 2002, 61, 381-389. [CrossRef] [PubMed]

35. Griffin, B.A. How relevant is the ratio of dietary n-6 to n-3 polyunsaturated fatty acids to cardiovascular risk? Evidence from the OPTILIP study. Curr. Opin. Lipidol. 2008, 19, 57-62. [CrossRef] [PubMed]

36. Stanley, J.C.; Elsom, R.L.; Calder, P.C. UK Food Standards Agency Workshop Report: The effects of the dietary n-6:n-3 fatty acid ratio on cardiovascular health. Br. J. Nutr. 2007, 98, 1305-1310. [CrossRef] [PubMed] 
37. Bhatt, D.L.; Steg, P.G.; Miller, M.; Brinton, E.A.; Jacobson, T.A.; Ketchum, S.B.; Doyle, R.T., Jr.; Juliano, R.A.; Jiao, L.; Granowitz, C.; et al. Cardiovascular risk reduction with icosapent ethyl for hypertriglyceridemia. N. Engl. J. Med. 2019, 380, 11-22. [CrossRef] [PubMed]

38. Adkins, Y.; Kelley, D.S. Mechanisms underlying the cardioprotective effects of omega-3 polyunsaturated fatty acids. J. Nutr. Biochem. 2010, 2, 781-792. [CrossRef]

39. Kalmijn, S.; Launer, L.J.; Ott, A.; Witteman, J.C.M.; Hofman, A.; Breteler, M.M.B. Dietary fat intake and the risk of incident dementia in the Rotterdam study. Ann. Neurol. 1997, 42, 776-782. [CrossRef]

40. Barberger-Gateau, P.; Letenneur, L.; Deschamps, V.; Peres, K.; Dartigues, J.F.; Renaud, S. Fish, meat and the risk of dementia: Cohort study. Br. J. Med. 2002, 325, 932-933. [CrossRef]

41. Morris, M.C.; Evans, D.A.; Bienias, J.L.; Tangney, C.C.; Bennett, D.A.; Wilson, R.S.; Aggarwal, N.; Schneider, J. Consumption of fish and n-3 fatty acids and the risk of incident Alzheimer disease. Arch. Neurol. 2003, 60, 940-946. [CrossRef]

42. Bazinet, R.P.; Laye, S. Polyunsaturated fatty acids and their metabolites in brain function and disease. Nat. Rev. Neurosci. 2014, 15, 771-785. [CrossRef]

43. Lee, L.K.; Shahar, S.; Chen, A.V.; Yusoff, N.A. Docosahexaenoic acid-concentrated fish oil supplementation in subjects with mild cognition impairment: A 12-month randomised double-blind placebo-controlled trial. Psychopharmacology 2013, 225, 605-612. [CrossRef] [PubMed]

44. Freund-Levi, Y.; Eriksdotter-Jonhagen, M.; Cederholm, T.; Basun, H.; Faxen-Irving, G.; Garlind, A.; Vedin, I.; Vessby, B.; Wahlund, L.O.; Palmblad, J. Omega-3 fatty acid treatment in 174 patients with mild to moderate Alzheimer disease: OmegAD study: A randomised double-blind trial. Arch. Neurol. 2006, 63, 1402-1408. [CrossRef] [PubMed]

45. Firth, J.; Teasdale, S.B.; Allott, K.; Siskind, D.; Marx, W.; Cotter, J.; Veronese, N.; Schuch, F.; Smith, L.; Solmi, M.; et al. The efficacy and safety of nutrient supplements in the treatment of mental disorders: A meta-review of meta-analyses of randomised controlled trials. World Psychiatry 2019, 18, 308-324. [CrossRef] [PubMed]

46. Gunstone, F.D.; Harwood, J.L.; Dijkstra, A. (Eds.) The Lipid Handbook, 3rd ed.; CRC Press: Boca Raton, FL, USA, 2007.

47. Tocher, D.R. Omega-3 long-chain polyunsaturated fatty acids and aquaculture in perspective. Aquaculture 2015, 449, 94-107. [CrossRef]

48. Gladyshev, M.I.; Sushchik, N.N. Long-chain omega-3 polyunsaturated fatty acids in natural ecosystems and the human diet: Assumptions and challenges. Biomolecules 2019, 9, 485. [CrossRef] [PubMed]

49. Ahlgren, G.; Lundstedt, L.; Brett, M.; Forsberg, C. Lipid composition and food quality of some freshwater phytoplankton for cladoceran zooplankters. J. Plankton Res. 1990, 12, 809-818. [CrossRef]

50. Muller-Navarra, D.C. Biochemical versus mineral limitation in Daphnia. Limnol. Oceanogr. 1995, 40, $1209-1214$. [CrossRef]

51. Wacker, A.; Becher, P.; Von Elert, E. Food quality effects of unsaturated fatty acids on larvae of the zebra mussel, Dreissena polymorpha. Limnol. Oceanogr. 2002, 47, 1242-1248. [CrossRef]

52. Chu, F.L.E.; Lund, E.D.; Podbesek, J.A. Quantitative significance of n-3 essential fatty acid contribution by heterotrophic protists in marine pelagic food webs. Mar. Ecol. Prog. Ser. 2008, 354, 85-95. [CrossRef]

53. Teoh, C.Y.; Ng, W.K. The implications of substituting dietary fish oil with vegetable oils on the growth performance, fillet fatty acid profile and modulation of the fatty acid elongase, desaturase and oxidation activities of red hybrid tilapia, Oreochromis sp. Aquaculture 2016, 465, 311-322. [CrossRef]

54. Colombo, S.M.; Rodgers, T.F.M.; Diamond, M.L.; Bazinet, R.P.; Arts, M.T. Projected declines in global DHA availability for human consumption as a result of global warming. Ambio 2019. [CrossRef] [PubMed]

55. Harwood, J.L.; Jones, A.L. Lipid Metabolism in Algae. In Advances in Botanical Research; Callow, J.A., Ed.; Academic Press: New York, NY, USA, 1989; pp. 1-53.

56. Pohl, P.; Zurheide, F.; Hoppe, H.A. Fatty acids and lipids of marine algae and the control of their synthesis by environmental factors. In Marine Algae in Pharmaceutical Science; Koppe, H.A., Levring, T., Tanaka, Y., Eds.; Walter de Gruyter: Berlin, Germany, 1979; pp. 437-523.

57. Ratledge, C.; Cohen, Z. Single Cell Oils: Microbial and Algal Oils; AOCS Press: Urbana, IL, USA, 2010.

58. Lang, I.K.; Hodac, L.; Friedl, T.; Feussner, I. Fatty acid profiles and their distribution patterns in microalgae: A comprehensive analysis of more than 2000 strains from the SAG culture collection. BMC Plant Biol. 2011, 11, 124. [CrossRef] [PubMed] 
59. Kendel, M.; Barnathan, G.; Fleurence, J.; Rabesaotra, V.; Wielgosz-Collin, G. Non-methylene interrupted and hydroxyl fatty acids in polar lipids of the alga Grateloupia turutura over the four seasons. Lipids 2013, 48, 535-545. [CrossRef] [PubMed]

60. Fleurence, J.; Gutbier, G.; Mabeau, S.; Leray, C. Fatty acids from 11 marine macroalgae of the French Brittany coast. J. Appl. Physiol. 1994, 6, 527-532. [CrossRef]

61. Van Ginneken, V.J.T.; Helsper, J.P.F.G.; de Visser, W.; van Keulen, H.; Brandenburg, W.A. Polyunsaturated fatty acids in various macroalgal species from North Atlantic and tropical seas. Lipids Health Dis. 2011, 10, 104. [CrossRef]

62. Li-Beisson, Y.; Shorrosh, B.; Beisson, F.; Andersson, M.X.; Arondel, V.; Bates, P.D. Acyl-lipid metabolism. Arabidopsis Book 2013, 8, e0161. [CrossRef]

63. Riekhof, W.R.; Sears, S.S.; Benning, C. Annotation of genes involved in glycerolipid biosynthesis in Chlamydomonas reinhardtii; discovery of the betaine lipid synthase BTA1(Cr). Eukaryot. Cell 2005, 4, 242-252. [CrossRef]

64. Moellering, R.; Miller, R.; Benning, C. Molecular genetics of lipid metabolism in the model green alga Chlamydomonas reinhardtii. In Lipids in Photosynthesis; Wada, H., Murata, N., Eds.; Springer: Dordrecht, The Netherlands, 2010; pp. 139-155.

65. Khozin-Goldberg, I.; Cohen, Z. Unraveling algal lipid metabolism: Recent advances in gene identification. Biochimie 2011, 93, 91-100. [CrossRef]

66. Khozin-Goldberg, I.; Iskandarov, U.; Cohen, Z. LC-PUFA from photosynthetic microalgae: Occurrence, biosynthesis and prospects in biotechnology. Appl. Microbiol. Biotechnol. 2011, 91, 905-915. [CrossRef]

67. Petroutsos, D.; Amiar, S.; Abida, H.; Dolch, L.J.; Bastien, O.; Rebeille, F.; Jouhet, J.; Falconet, D.; Block, M.A.; McFadden, G.I.; et al. Evolution of galactoglycerolipid biosynthetic pathways-From cyanobacteria to primary plastids and from primary to secondary plastids. Prog. Lipid Res. 2014, 54, 68-85. [CrossRef]

68. Banerjee, A.; Maiti, S.K.; Guria, C.; Banerjee, C. Metabolic pathways for lipid synthesis under nitrogen stress in Chlamydomonas and Nannochloropsis. Biotechnol. Lett. 2017, 39, 1-11. [CrossRef] [PubMed]

69. Vieler, A.; Wu, G.; Tsai, C.-H.; Bullard, B.; Cornish, A.J.; Harvey, C. Genome, functional gene annotation, and nuclear transformation of the heterokont oleaginous alga Nannochloropsis oceanica CCMP1779. PLoS Genet. 2012, 8, e1003064. [CrossRef] [PubMed]

70. Sato, N.; Moriyama, T.; Mori, N.; Toyoshima, M. Lipid metabolism and potentials of biofuel and high added-value oil production in red algae. World J. Microbiol. Biotechnol. 2017, 33, 11. [CrossRef] [PubMed]

71. Sayanova, O.; Mimouni, T.; Mori, N.; Toyoshima, M. Modulation of lipid biosynthesis by stress in diatoms. Philos. Trans. R. Soc. B Biol. Sci. 2017. [CrossRef] [PubMed]

72. Liu, B.; Benning, C. Lipid metabolism in microalgae distinguishes itself. Curr. Opin. Biotechnol. 2013, 24, 300-309. [CrossRef]

73. Merchant, S.S.; Kropat, J.; Liu, B.; Shaw, J.; Warakanont, J. TAG, You're it! Chlamydomonas as a reference organism for understanding algal triacylglycerol accumulation. Curr. Opin. Biotechnol. 2012, 23, 352-363.

74. Li-Beisson, Y.; Beisson, F.; Riekhof, W. Metabolism of acyl lipids in Chlamydomonas reinhardtii. Plant J. 2015, 82, 504-522. [CrossRef]

75. Li, N.; Xu, C.; Li-Beisson, Y.; Philippar, K. Fatty acid and lipid transport in plant cells. Trends Plant Sci. 2016, 21, 145-158. [CrossRef]

76. Khozin-Goldberg, I.; Didi-Cohen, S.; Shayakhmetova, I.; Cohen, Z. Biosynthesis of eicosapentaenoic acid (EPA) in the freshwater eustigmatophyte Monodus subterraneus. J. Phycol. 2002, 38, 745-756. [CrossRef]

77. Khozin, I.; Adlerstein, D.; Bigongo, C.; Heimer, Y.M.; Cohen, Z. Elucidation of the biosynthesis of eicosapentaenoic acid in the microalga Porphyridium cruentum. II. Studies with radioactive precursors. Plant Physiol. 1997, 114, 223-230. [CrossRef]

78. Metz, J.G.; Roessler, P.; Facciotti, D.; Levering, C.; Dittrich, F.; Lassner, M.; Valentine, R.; Lardizabal, K.; Domergue, F.; Yamada, A.; et al. Production of polyunsaturated fatty acids by polyketide synthases in both prokaryotes and eukaryotes. Science 2001, 293, 290-293. [CrossRef] [PubMed]

79. Harwood, J.L.; Guschina, I.A. The versatility of algae and their lipid metabolism. Biochimie 2009, 91, 679-684. [CrossRef] [PubMed]

80. Kris-Etherton, P.M.; Grieger, J.A.; Etherton, T.D. Dietary reference intakes for DHA and EPA. Prostaglandins Leukot. Essent. Fat. Acids 2009, 81, 99-104. [CrossRef] [PubMed] 
81. Hutchings, J.A.; Reynolds, J.D. Marine fish population collapses: Consequences for recovery and extinction risk. Bioscience 2004, 54, 297-309. [CrossRef]

82. Tocher, D. Issues surrounding fish as a source of omega-3 long-chain polyunsaturated fatty acids. Lipid Technol. 2009, 21, 13-16. [CrossRef]

83. Adarme-Vega, T.C.; Thomas-all, S.R.; Schenk, P.M. Towards sustainable sources for omega-3 fatty acids production. Curr. Opin. Biotechnol. 2014, 26, 14-18. [CrossRef]

84. Twining, C.W.; Brenna, J.T.; Hairston, N.G.; Flecker, A.S. Highly unsaturated fatty acids in nature: What do we know and what we need to learn. Oikos 2015, 125, 749-760. [CrossRef]

85. Bascoul-Colombo, C.; Guschina, I.A.; Maskrey, B.H.; Good, M.; O’Donnell, V.B.; Harwood, J.L. Dietary DHA supplementation causes selective changes in phospholipids from different brain regions in both wild type mice and the Tg2576 mouse model of Alzheimer's disease. Biochim. Biophys. Acta 2016, 1861, 524-537. [CrossRef]

86. Fuschino, J.R.; Guschina, I.A.; Dobson, G.; Yan, N.D.; Harwood, J.L.; Arts, M.T. Rising water temperatures alter lipid dynamics and reduce n-3 essential fatty acid concentrations in Scenedesmus obliquus. J. Phycol. 2011, 47, 763-774. [CrossRef]

87. Du, Z.Y.; Benning, C. Triacylglycerol accumulation in photosynthetic cells in plants and algae. Subcell. Biochem. 2016, 86, 179-205.

88. Aslan, S.; Kapdan, I.K. Batch kinetics of nitrogen and phosphorus removal from synthetic waste water by algae. Ecol. Eng. 2006, 28, 64-70. [CrossRef]

89. Hu, Q.; Sommerfeld, M.; Jarvis, E.; Ghirardi, M.; Posewitz, M.; Siebert, M. Microalgal triacylglycerols as feedstocks for biofuel production: Perspectives and advances. Plant J. 2008, 54, 621-639. [CrossRef] [PubMed]

90. Simionato, D.; Block, M.A.; La Rocca, N.; Jouhet, J.; Marechal, E.; Finazzi, G.; Morosinotto, T. The response of Nannochloropsis gaditana to nitrogen starvation includes de novo biosynthesis of triacylglycerol, a decrease of chloroplast galactolipids and reorganisation of the photosynthetic apparatus. Eukaryot. Cell 2013, 12, 665-676. [CrossRef]

91. Abida, H.; Dolch, L.-J.; Mei, C.; Villanova, V.; Conte, M.; Block, M.A.; Finazzi, G.; Bastien, O.; Tirichine, L.; Bowler, C.; et al. Membrane glycerolipid remodelling triggered by nitrogen and phosphorus starvation in Phaeodactylum tricornutum. Plant Physiol. 2015, 167, 118-136. [CrossRef] [PubMed]

92. Boyle, N.R.; Page, M.D.; Liu, B.; Blaby, I.K.; Casero, D.; Kropat, J.; Cokus, S.J.; Hong-Hermesdorf, A.; Shaw, J.; Karpowicz, S.J.; et al. Three acyltransferases and nitrogen-responsive regulator are implicated in nitrogen starvation-induced triacylglycerol accumulation in Chlamydomonas. J. Biol. Chem. 2012, 287, 15811-15825. [CrossRef] [PubMed]

93. Levitan, O.; Dinamarca, J.; Zelzion, E.; Lun, D.S.; Guerra, L.T.; Kim, M.K.; Kim, J.; Van Mooy, B.A.; Bhattacharya, D.; Falkowski, P.G. Remodeling of intermediate metabolism in the diatom Phaeodactylum tricornutum under nitrogen stress. Eukaryot. Cell 2013, 12, 665-676.

94. Goncalves, E.C.; Wilkie, A.C.; Kirst, M.; Rathinasabapathi, B. Metabolic regulation of triacylglycerol accumulation in the green algae: Identification of potential targets for engineering to improve oil yield. Plant Biotechnol. 2016, 14, 1649-1660. [CrossRef]

95. Riekhof, W.R.; Ruckle, E.; Lydic, T.A.; Sears, B.B.; Benning, C. The sulpholipids 2'-O-acylsulfoquinovosyldiacylglycerol and sulphoquinovosyldiacylglycerol are absent from a Chlamydomonas reinhardtii mutant deleted in SQD1. Plant Physiol. 2003, 133, 864-874. [CrossRef]

96. Khozin-Goldberg, I.; Cohen, Z. The effect of phosphate starvation on the lipid and fatty acid composition of the freshwater eustigmatophyte Monodus subterraneus. Phytochemistry 2006, 67, 696-701. [CrossRef]

97. Zulu, N.N.; Zienkiewicz, K.; Vollhyde, K.; Feussner, I. Currents trends to comprehend lipid metabolism in diatoms. Prog. Lipid Res. 2018, 70, 1-16. [CrossRef]

98. Adams, C.; Bugbee, B. Enhancing lipid production of the marine diatom Chaetoceros gracilis: Synergistic interactions of sodium chloride and silicon. J. Appl. Phycol. 2014, 26, 1351-1357. [CrossRef]

99. Jiang, Y.; Nunez, M.; Laverty, K.S.; Quigg, A. Coupled effect of silicate and nickel on the growth and lipid production in the diatom Nitzschia perspicua. J. Appl. Phycol. 2015, 27, 1137-1148. [CrossRef]

100. Zhao, P.; Gu, W.; Wu, A.; Huang, A.; He, L.; Xie, X. Silicon enhances the growth of Phaeodactylum tricornutum Bohlin under green light and low temperature. Sci. Rep. 2014, 4, 3958. [CrossRef] [PubMed] 
101. Legeret, B.; Schulz-Raffelt, M.; Nguyen, H.M.; Auroy, P.; Beisson, F.; Peltier, G.; Blanc, G.; Li-Beisson, Y. Lipidomic and transcriptomic analyses of Chlamydomonas reinhardtii under heat stress unveil a direct route for the conversion of membrane lipids into storage lipids. Plant Cell Environ. 2016, 39, 834-847. [CrossRef] [PubMed]

102. Schroda, M.; Hemme, D.; Muhlhaus, T. The Chlamydomonas heat stress response. Plant J. 2015, 82, 466-480. [CrossRef]

103. Hibbeln, J.R.; Nieminen, I.R.; Blasbalg, T.L.; Riggs, J.A.; Lands, W.E. Healthy intakes of n-3 and n-6 fatty acids: Estimations considering worldwide diversity. Am. J. Clin. Nutr. 2006, 83 (Suppl. 6), 1483s-1493s. [CrossRef]

104. ISSFAL, Recommendations for intake of polyunsaturated fatty acids in healthy adults. Issfal News 2004, 11, 12-25.

105. Spolaore, P.; Joannis-Cassan, C.; Duran, E.; Isambert, A. Commercial applications of microalgae. J. Biosci. Bioeng. 2006, 101, 87-96. [CrossRef]

106. Breivik, H. (Ed.) Long-Chain Omega-3 Speciality Oils; The Oily Press: Bridgwater, UK, 2007.

107. Tocher, D.R.; Bell, J.G.; Dick, J.R.; Crampton, V.O. Effects of dietary vegetable oils on Atlantic salmon hepatocyte fatty acid desaturation and liver fatty acid compositions. Lipids 2003, 38, 723-732. [CrossRef]

108. IFFO. The Marine Ingredients Organisation: Fishmeal and Fish Oil Statistical Yearbook 2016. Available online: www.iffo.net (accessed on 10 October 2019).

109. Patil, V.; Kallqvist, T.; Olsen, E.; Vogt, G.; Gislerod, H.R. Fatty acid composition of 12 microalgae for possible use in aquaculture feed. Aquac. Int. 2007, 15,1-9. [CrossRef]

110. Ganuza, E.; Benitez-Santana, T.; Atalah, E.; Vega-Orellana, O.; Ganga, R.; Isquierdo, M.S. Crypthecodinium cohnii and Schizochytrium sp. as potential substitutes in fisheries-derived oils from seabream (Sparus aurata) microdiets. Aquaculture 2008, 277, 109-116. [CrossRef]

111. Yongmanitchal, W.; Ward, O.P. Growth of and omega-3 fatty acid production by Phaeodactylum tricornutum under different culture conditions. Appl. Environ. Microbiol. 1991, 57, 419-425.

112. Suzenik, A. Ecophysiological considerations in the optimisation of eicosapentaenoic acid production by Nannochloropsis sp. (Eustigmatophyceae). Bioresour. Technol. 1991, 35, 263-269. [CrossRef]

113. Adarme-Vega, T.C.; Lim, D.K.; Timmins, M.; Vernen, F.; Li, Y.; Schenk, P.M. Microalgal biofactories: A promising approach towards sustainable omega-3 fatty acid production. Microb. Cell Fact. 2012, 11, 96. [CrossRef] [PubMed]

114. Wen, Z.; Chen, F. Production of eicosapentaenoic acid using heterotrophically grown microalgae. In Single Cell Oils, 2nd ed.; Cohen, Z., Ratledge, C., Eds.; AOCS Press: Urbana, IL, USA, 2010; pp. 151-177.

115. Pal, D.; Khozin-Goldberg, I.; Didi-Cohen, S.; Solovchenko, A.; Batushansky, A.; Kaye, Y.; Sikron, N.; Samani, T.; Fait, A.; Boussiba, S. Growth, lipid production and metabolic adjustments in the euryhaline eustigmatophyte Nannochloropsis oceanica CCALA 804 in response to osmotic downshift. Appl. Microbiol. Biotechnol. 2013, 97, 8291-8306. [CrossRef] [PubMed]

116. Chauton, M.S.; Reitan, K.I.; Nosker, N.H.; Tveteras, R.; Kleivdal, H.T. A technoeconomic analysis of industrial production of marine microalgae as a source of EPA and DHA-rich raw material for aquafeed: Research challenges and possibilities. Aquaculture 2015, 463, 95-103. [CrossRef]

117. Rezanka, T.; Petrankova, M.; Cepak, V.; Pribyl, P.; Sigler, K.; Cajthami, T. Trachydiscus minutus, a new biotechnological source of eicosapentaenoic acid. Folia Microbiol. 2010, 55, 265-269. [CrossRef]

118. Rezanka, T.; Lukavsky, J.; Nedbalova, L.; Sigler, K. Effect of nitrogen and phosphorus starvation on the polyunsaturated triacylglycerol composition, including isomer distribution, in the alga Trachydiscus minutus. Phytochemistry 2011, 72, 2342-2351. [CrossRef]

119. Hamilton, L.; Haslam, R.P.; Napier, J.A.; Sayanova, O. Metabolic engineering of Phaeodactylum tricornutum for the enhanced production of omega-3 long chain polyunsaturated fatty acids. Metab. Eng. 2014, 22, 3-9. [CrossRef]

120. Khozin-Goldberg, I.; Leu, S.; Boussiba, S. Microalgae as a source for VLC-PUFA production. Subcell. Biochem. 2016, 86, 471-510.

121. Wen, Z.-Y.; Chen, F. Heterotrophic production of eicosapentaenoic acid by microalgae. Biotechnol. Adv. 2003, 21, 273-294. [CrossRef]

122. Winwood, R.J. Recent developments in the commercial production of DHA and EPA rich oils from micro-algae. OCL 2013, 20, D604. [CrossRef] 
123. Haimeur, A.; Ulmann, L.; Mimouni, V.; Gueno, F.; Pineau-Vincent, F.; Meskini, N.; Tremblin, G. The role of Odontella aurita, a marine diatom rich in EPA, as a dietary supplement in dyslipidemia, platelet function and oxidative stress in high-fat fed rats. Lipids Health Dis. 2012, 11, 147. [CrossRef] [PubMed]

124. Barclay, W.; Weaver, C.; Metz, J.; Hansen, J. Development of a docosahexaenoic acid production technology using Schizochytrium: Historical perspective and update. In Single Cell Oils, 2nd ed.; Cohen, Z., Ratledge, C., Eds.; AOCS Press: Urbana, IL, USA, 2010; pp. 75-96.

125. Muhlroth, A.; Li, K.; Rokke, G.; Winge, P.; Olsen, Y.; Hohmann-Marriott, M.F.; Vadstein, O.; Bones, A.M. Pathways of lipid metabolism in marine algae, co-expression network, bottlenecks and candidate genes for enhanced production of EPA and DHA in species of Chromista. Mar. Drugs 2013, 11, 4662-4697. [CrossRef] [PubMed]

126. Chopin, T.; Chopin, T.; Couturier, C. Seaweed aquaculture- from the global, mostly Asian, picture to the opportunities and constraints of the Canadian scene. Bull. Aquac. Assoc. Can. 2017, 1, 3-8.

127. Available online: www.worldfishing.net/news101/regional-focus/philippines3 (accessed on 10 October 2019).

128. Ratledge, C. Single cell oils for the 21st century. In Single Cell Oils, 2nd ed.; Cohen, Z., Ratledge, C., Eds.; AOCS Press: Urbana, IL, USA, 2010; pp. 3-26.

129. Abril, J.R.; Wills, T.; Harding, F. Applications of single cell oils for animal nutrition. In Single Cell Oils, 2nd ed.; Cohen, Z., Ratledge, C., Eds.; AOCS Press: Urbana, IL, USA, 2010; pp. 389-419.

130. Velasco-Escudero, M.; Gong, H. Applications of single cell oils for aquaculture. In Single Cell Oils, 2nd ed.; Cohen, Z., Ratledge, C., Eds.; AOCS Press: Urbana, IL, USA, 2010; pp. 421-436.

131. Santigosa, E.; Verlhac-Trichet, V.; Olsen, R.E.; Figuereido-Silva, C.A. A microalgal oil containing EPA+DHA can be an effective source of omega-3 for Atlantic salmon post-smolts. In Proceedings of the 18th International Symposium on Fish Nutrition and Feeding (ISFNF), Las Palmas, Spain, 3-7 June 2018; Abstract 3.20.

132. Ruyter, B.; Sissener, N.H.; Ostbye, T.-K.; Simon, C.J.; Krasnov, A.; Bou, M.; Sanden, M.; Nichols, P.D.; Lutfi, E.; Berge, G.M. Omega-3 Canola oil effectively replaces fish oil as a dietary source of docosahexaenoic acid (DHA) in feed for Atlantic salmon in freshwater and seawater. In Proceedings of the 18th International Symposium on Fish Nutrition and Feeding (ISFNF), Las Palmas, Spain, 3-7 June 2018; Abstract 3.02.

(C) 2019 by the author. Licensee MDPI, Basel, Switzerland. This article is an open access article distributed under the terms and conditions of the Creative Commons Attribution (CC BY) license (http://creativecommons.org/licenses/by/4.0/). 